pression ratio gives it an important flexibility. Besides the assistance given to the world by the supply of cheap power in huge quantities after the War of 1914-18, the years since have seen a great development in the methods of manufacture. One lesson we must learn from the present War is that we must no longer neglect the manufacture of highgrade machine tools. The reasons are not necessarily technical; they are more in the economic field, but the high reputation we now have for very elaborate products should leave no one in doubt in the future that we can turn out small-grade machine tools of an excellent quality.

\section{0-Million Volt Cyclotron to be Built in Moscow}

THE construction of a very powerful cyclotron, capable of producing 50 million electron volt deuterons, will be commenced in Moscow early in 1941, according to a decision of the Academy of Sciences of the U.S.S.R., based on a report submitted by the Physical Institute of the Academy. A magnet the core of which weighs about 1,000 tons and solenoid of 18 tons is to be installed. A special building to house the cyclotron will be erected in the grounds of the new home of the Physical Institute of the Academy being built on the Bolshaya Kaluzhskaya Ulitsa in Moscow. The old apparatus in the Soviet Union, which is in the Radium Institute of Leningrad, is capable of giving an energy of 4 million electron volts to particles; another, nearing completion at the Physico-Technical Institute, also in Leningrad, will be capable of imparting an energy of 10-12 million electron volts.

\section{Fossil Skeleton of Uintatherium}

AN almost complete skeleton of Uintatherium, a six-horned animal the size of an elephant which dominated the primitive forests of southern Wyoming about thirty million years ago, has been found by Dr. Charles L. Gazin, palæontologist of the Smithsonian Institution. Bones of this giant mammal are common; but a skeleton with only a few parts missing is rare. Dr. Gazin's find lacks only one hind leg, part of a foreleg, and the neck vertebræ. The skull, about three feet long, is in exceptionally good condition, although the lower jaw is considerably crushed. There is also a second skull, including one of the beast's sabre-like down-pointed tusks about a foot long. The skeleton is expected to become one of the main exhibits in the U.S. National Museum, after it has been worked free from the matrix of hardened clay in which it is embedded, and properly mounted. This work may require as much as a year.

\section{Recent Earthquakes}

AN earthquake of considerable severity shook the island of New Britain, which is to the north-east of New Guinea, early on January 14. The epicentre appears to have been near Keravat, where houses collapsed. Keravat is some twenty-five miles from the port of Rabaul, where some faulting occurred, damaging the harbour. An earthquake of intensity 7 or 8 on the Rossi-Forel scale was felt at Rabaul on September 12, 1940, at 11.20 p.m. local time, the shock lasting for some three minutes and then decreasing in severity. Seventy-two distinct tremors were felt between then and 8.30 a.m. on September 13 . The epicentre was judged to be about 70 miles southsouth-east of Rabaul, and the shock was severely felt in the Kokopo District and at Wide Bay, Pondo, Namatanai and Buka.

On December 12 an earthquake was registered on the short-period instruments at Kew Observatory at 21h. $20 \mathrm{~m}$. 4ls. G.M.T. There were only slight traces on the Galitzin seismograms. The earthquake was calculated to have had its epicentre some $290 \mathrm{~km}$. distant from Kew and was thus a 'near' earthquake. About this time a shock was reported from Penrhos in North Wales. On December 28 a moderately strong earthquake, giving maximum ground amplitude of $21 \mu$ was registered at $16 \mathrm{~h} .51 \mathrm{~m}$. 54s. G.M.T. It was calculated to have had its epicentre some 11,600 km. away and was thus a 'distant' earthquake. A full suite of well-registered waves was observed.

\section{Announcements}

Sir William Beveridge, who has been chairman of the man-power survey of the Ministry of Labour and National Service, has been appointed an undersecretary in the Ministry. It is stated that the manpower survey has been completed, and Sir William Beveridge will now have administrative responsibility for the section of the Ministry dealing with manpower requirements of industry and the Armed Forces.

Mrs. Neville-Rolfe, secretary-general of the British Social Hygiene Council, has been awarded the Snow Medal for 1941 by the American Social Hygiene Association. The medal is given for "distinguished service to humanity", and is named after Dr. Snow, the first director of the American Association, founded in 1913. Mrs. Neville-Rolfe is the fourth recipient of the medal and the first woman to receive it.

OwING to war conditions, the Industrial Health Education Society, which started its activities in 1927, has resolved to close down its work in arranging for talks on the requirements for industrial health. Its remaining funds are being handed over to the British Medical Association to establish a Mackenzie Lectureship on industrial hygiene in memory of Sir James Mackenzie, who began the work.

The Clough Memorial Research Fund was instituted in 1935 for the purpose of encouraging geological research in Scotland and the North of England. The North of England is defined as comprising the counties of Northumberland, Cumberland, Durham, Westmorland, and Yorkshire. Under the terms of administration of the fund a sum of approximately $£ 30$ is available annually. Applications for grants are invited for the period April 1, 1941-March 31, 1942, and should be made to the Secretary, Clough Research Fund Committee, Edinburgh Geological Society, Synod Hall, Castle Terrace, Edinburgh, not later than March 1 . 